\title{
CLINES IN THE COLOUR POLYMORPHISM OF PHILAENUS SPUMARIUS IN EASTERN CENTRAL EUROPE
}

\author{
O. HALKKA, M. RAATIKAINEN and J. VILBASTE \\ Department of Genetics, University of Helsinki, Finland; Department of Biology, University of \\ Jyväskylä, Finland; Institute of Zoology and Botany, Academy of Sciences, Tartu, Estonian \\ SSR
}

Received 3.iii.75

\section{SUMMARY}

Populations of Philaenus spumarius (Homoptera) have been investigated in the Baltic States of the USSR, in Czechoslovakia and in Hungary. Colour morph frequencies in these highly polymorphic populations are compared with those reported earlier from northern Italy.

Gradual changes in allele frequencies (clines) transect the study area, which lies in the most central part of the range of Philaenus in Europe. From north to south the allele $p^{M}$ increases, but $p^{O}$ decreases, in frequency. In their distribution, some of the other alleles also showed regional gradients.

The possibility that visual selection varies regionally is dismissed on indirect grounds. Gradients in climatic severity, or in other environmental variables changing concomitantly with climate, are regarded as the primary cause of the observed clines and other differences between regions.

\section{INTRODUCTION}

THE colour polymorphism of the meadow spittlebug, Philaenus spumaris (L.) (Homoptera), is determined by combinations of at least seven allelic genes of the $p$ (for "pigmentation") locus plus a number of non-allelic modifier genes (Halkka et al., 1975). In Europe, except in the northernmost parts and in some isolates, the various genotypes are expressed as more than 10 distinct phenotypes. In many respects, the polymorphism of this insect offers a useful parallel for comparison with the colour polymorphisms in the equally widely distributed but more extensively investigated snails of the helicid group. In the snails, notably in Cepaea, the relative importance of various types of selection is now being discussed (e.g. Jones, 1973).

In Philaenus regional differences in climatic or other non-visual types of selection are manifest as clines hundreds of kilometres in extent, or as area effects of more limited dimensions (Halkka, 1964; Halkka, Raatikainen and Halkka, 1974). But all the work on regional differences accomplished hitherto has been with the populations of northern Europe. The only more southern populations studied critically with regard to regional distribution of colour morphs are those investigated by Raatikainen (1971) in northern Italy.

The present study is an effort to fill in the wide gap between the populations of northern Europe and Italy, and deals with populations from the Baltic States of the USSR, from Czechoslovakia, and from Hungary. One particular topic studied is the possibility that there are clines transecting the European centre of the range of the species. Hitherto, clines have been known only from the periphery of the range. 


\section{Collecting}

From the Baltic States, 11 samples were collected from Estonia, 4 from Latvia and 4 from Lithuania. The 5 samples from Czechoslovakia comi from the eastern half of that country, and the 2 samples from Hungary from the western part of the central plain. Most of the samples are from rathe: open meadow habitats, and almost all are from quite low altitudes.

The Hungarian samples were collected in June 1974, the Czechoslovakiar ones in July 1967, and the Baltic ones in July-August 1966. The Philaenu populations are temporally very stable (Halkka, 1964), and it appears safi to compare samples collected in different years.

\section{RESUlts}

In Tables 1 and 2, the populations are listed with the northern-mos ones at the top. Males and females are presented separately, because man of the colour alleles are not (normally) expressed in the males (Halkka et al. 1975).

\section{TABLE 1}

Percentages of the six colour morphs among the males. The numbers after the name of each populatio: denote latitude and longitude (e.g.: Toila, 59 $30^{\prime} \mathcal{N}, 27^{\circ} 40^{\prime} \mathrm{E}$ ). Total number of males examine. at right

Estonian SSR

Toila 5930-2740

typ

Vaida 5925-2500

Haapsalu 5850-2330

Matsalu 5845-2345

Vändra 5840-2300

Pöltsamaa 5840-2550

Soonda $5835-2320$

Soe $5825-2240$

Pärnu 5820-2445

Mikitamäe $5800-2725$

Hargla 5735-2635

$94 \cdot 6$

$97 \cdot 7$

$90 \cdot 6$

$81 \cdot 6$

$96 \cdot 9$

$94 \cdot 6$

$82 \cdot 4$

$86 \cdot 6$

$88 \cdot 0$

$87 \cdot 4$

$89 \cdot 7$

tri

fla

$l o p$
$2 \cdot 7$
$0 \cdot 4$
$1 \cdot 7$
$10 \cdot 2$
$0 \cdot 4$
$1 \cdot 7$
$14 \cdot 7$
$7 \cdot 2$
$5 \cdot 8$
$5 \cdot 5$
$6 \cdot 3$

pra

vit

Total

Latvian SSR

Valmiera 5735-2525

Saulkrasti 5725-2430

Baldone 5650-2415

Kalnciems 5640-2540

Lithuanian SSR

Birzai 5615-2435

Telsai 5600-2220

Kapsukas 5440-2520

Punia 5435-2400

Czechoslovakia

Ruzomberok 4900-1915

Straznice 4855-1720

Roznava 4840-2030

Caradice 4830-1845

Smolenice $4825-1730$

$68 \cdot 8$

$88 \cdot 0$

$88 \cdot 6$

$95 \cdot 1$

$87 \cdot 9$

\section{Hungary}

Szigliget 4655-1735

Nagykanizsa 4630-1700

$5 \cdot 1$
$2 \cdot 3$
$1 \cdot 0$
$2 \cdot 3$

\section{$2 \cdot 5$}

\section{$4 \cdot 4$}

$-$ 
The hierarchy of the alleles is rather complex. Roughly, the order of dominance, in the female sex, is as follows: $p^{T}($ tri $)-p^{M}($ mar $)-p^{L}($ lat $)=p^{F}$ $(f l a)=p^{C}(l c e)-p^{O}(l o p)-p^{t}(t y p)$. In this scheme, - denotes dominance, and $=$ co-dominance.

The frequency of each phenotype or group of phenotypes representing a specific allele is expressed as a percentage of the male or female sample size. In every table the sample size is given on the right.

TABLE 2

Percentages of the nine colour morphs among the females. Total number of females examined at right

\begin{tabular}{|c|c|c|c|c|c|c|c|c|c|c|}
\hline Estonian SSR & $t y p$ & tri & lat & mar & $f a$ & lce & $l o p$ & pra & vit & Total \\
\hline Toila & $70 \cdot 6$ & 0.2 & $3 \cdot 1$ & $0 \cdot 2$ & $4 \cdot 6$ & $3 \cdot 9$ & $17 \cdot 2$ & 0.2 & - & 458 \\
\hline Vaida & $82 \cdot 5$ & 1.8 & $0 \cdot 6$ & $0 \cdot 6$ & $4 \cdot 6$ & $1 \cdot 4$ & $8 \cdot 5$ & - & - & 495 \\
\hline Haapsalu & $79 \cdot 0$ & 0.2 & $3 \cdot 1$ & $1 \cdot 0$ & $7 \cdot 3$ & $1 \cdot 1$ & $8 \cdot 4$ & - & - & 524 \\
\hline Matsalu & 71.7 & 1.3 & $4 \cdot 1$ & $1 \cdot 0$ & $4 \cdot 1$ & 1.5 & $14 \cdot 0$ & $2 \cdot 0$ & $0 \cdot 3$ & 392 \\
\hline Vändra & $76 \cdot 6$ & 1.9 & 1.7 & $0 \cdot 2$ & $10 \cdot 3$ & 1.4 & $7 \cdot 9$ & - & - & 582 \\
\hline Pöltsamaa & $79 \cdot 0$ & 1.8 & $1 \cdot 1$ & $0 \cdot 7$ & $6 \cdot 3$ & $2 \cdot 0$ & $8 \cdot 9$ & 0.2 & - & 447 \\
\hline Soonda & $75 \cdot 2$ & $2 \cdot 6$ & $0 \cdot 7$ & - & $8 \cdot 9$ & $0 \cdot 7$ & $11 \cdot 9$ & - & - & 270 \\
\hline Soe & $72 \cdot 5$ & $6 \cdot 4$ & $0 \cdot 4$ & $2 \cdot 1$ & $9 \cdot 5$ & $2 \cdot 9$ & $5 \cdot 8$ & $0 \cdot 4$ & - & 485 \\
\hline Pärnu & $70 \cdot 6$ & $2 \cdot 7$ & $0 \cdot 3$ & $1 \cdot 2$ & $6 \cdot 4$ & $1 \cdot 2$ & $16 \cdot 4$ & 0.9 & $0 \cdot 3$ & 329 \\
\hline Mikitamäe & $70 \cdot 2$ & $6 \cdot 2$ & $0 \cdot 4$ & $1 \cdot 8$ & $10 \cdot 5$ & 1.9 & $7 \cdot 8$ & 1.0 & - & 514 \\
\hline Hargla & $72 \cdot 2$ & $3 \cdot 2$ & $0 \cdot 6$ & $1 \cdot 3$ & $10 \cdot 4$ & $2 \cdot 2$ & $9 \cdot 8$ & $0 \cdot 3$ & - & 317 \\
\hline \multicolumn{11}{|l|}{ Latvian SSR } \\
\hline Valmiera & $73 \cdot 8$ & $3 \cdot 4$ & $0 \cdot 2$ & $\begin{aligned} 0 \cdot 6 \\
0\end{aligned}$ & $\begin{array}{l}9 \cdot 6 \\
9 \cdot 9\end{array}$ & $\begin{array}{l}2 \cdot 1 \\
1 \cdot 8\end{array}$ & $\begin{array}{l}9 \cdot 9 \\
7 \cdot 6\end{array}$ & $\begin{array}{l}0.4 \\
0.4\end{array}$ & - & $\begin{array}{l}477 \\
567\end{array}$ \\
\hline Saulkrasti & $76 \cdot 9$ & $2 \cdot 3$ & $0 \cdot 9$ & $\begin{array}{l}0 \cdot 2 \\
2 \cdot 2\end{array}$ & $\begin{array}{r}9 \cdot 9 \\
17 \cdot 6\end{array}$ & $\begin{array}{l}1.8 \\
3.7\end{array}$ & $\begin{array}{l}7 \cdot 6 \\
7 \cdot 4\end{array}$ & $\underline{0 \cdot 4}$ & - & $\begin{array}{l}56 / \\
136\end{array}$ \\
\hline Baldone & $\begin{array}{l}64 \cdot 0 \\
68 \cdot 2\end{array}$ & $\begin{array}{l}5 \cdot 1 \\
3 \cdot 0\end{array}$ & $\overline{0 \cdot 4}$ & $\begin{array}{l}2 \cdot 2 \\
0.2\end{array}$ & $\begin{array}{r}17 \cdot 0 \\
7 \cdot 6\end{array}$ & $2 \cdot 2$ & $17 \cdot 1$ & $1 \cdot 3$ & - & 463 \\
\hline Kalnciems & $08 \cdot 2$ & & & & & & & & & \\
\hline \multicolumn{11}{|l|}{ Lithuanian SSR } \\
\hline Birzai & $67 \cdot 0$ & $4 \cdot 3$ & $1 \cdot 2$ & 0.7 & $14 \cdot 5$ & $0 \cdot 7$ & $10 \cdot 7$ & $0 \cdot 7$ & $0 \cdot 2$ & 422 \\
\hline Telsai & $70 \cdot 7$ & $3 \cdot 5$ & $0 \cdot 2$ & 0.4 & $12 \cdot 7$ & $2 \cdot 9$ & $8 \cdot 1$ & $1 \cdot 3$ & $0 \cdot 2$ & 520 \\
\hline Kapsukas & $68 \cdot 1$ & $3 \cdot 4$ & $0 \cdot 2$ & $2 \cdot 6$ & $10 \cdot 9$ & $5 \cdot 4$ & $7 \cdot 6$ & 1.0 & 0.8 & 503 \\
\hline Punia & $51 \cdot 9$ & $2 \cdot 6$ & $1 \cdot 4$ & $3 \cdot 2$ & $19 \cdot 0$ & $5 \cdot 4$ & $16 \cdot 3$ & 一 & $0 \cdot 2$ & 496 \\
\hline \multicolumn{11}{|l|}{ Czechoslovakia } \\
\hline Ruzomberok & $55 \cdot 9$ & $6 \cdot 8$ & $1 \cdot 1$ & $2 \cdot 3$ & $9 \cdot 0$ & 11.9 & $9 \cdot 6$ & $2 \cdot 8$ & $0 \cdot 6$ & 177 \\
\hline Straznice & $82 \cdot 3$ & $3 \cdot 1$ & - & $4 \cdot 2$ & $3 \cdot 4$ & $0 \cdot 8$ & $3 \cdot 1$ & - & $3 \cdot 1$ & 26 \\
\hline Roznava & $74 \cdot 6$ & $3 \cdot 1$ & - & 1.6 & 8.6 & $4 \cdot 7$ & $2 \cdot 0$ & $2 \cdot 7$ & $2 \cdot 7$ & 25 \\
\hline Caradice & $81 \cdot 8$ & $2 \cdot 8$ & - & $7 \cdot 0$ & $4 \cdot 2$ & $2 \cdot 1$ & 1.4 & - & $0 \cdot 7$ & 143 \\
\hline Smolenice & 81.7 & $2 \cdot 8$ & $1 \cdot 5$ & 5.8 & $2 \cdot 6$ & $0 \cdot 4$ & $2 \cdot 6$ & $0 \cdot 4$ & $2 \cdot 2$ & 462 \\
\hline \multicolumn{11}{|l|}{ Hungary } \\
\hline Szigliget & $81 \cdot 6$ & - & - & $10 \cdot 5$ & - & - & $5 \cdot 3$ & - & $2 \cdot 6$ & 38 \\
\hline Nagykanizsa & $81 \cdot 4$ & $5 \cdot 1$ & - & 1.7 & $3 \cdot 4$ & - & $3 \cdot 4$ & - & $5 \cdot 1$ & \\
\hline
\end{tabular}

In the following discussion, the populations from Estonia, Latvia and Lithuania will be designated " the Baltic group ", or " B ", and the populations from Czechoslovakia and Hungary will be dealt with together as " GZ-H". Many of the colour morphs show distinctly dissimilar frequencies in $\mathrm{B}$ and $\mathrm{CZ}-\mathrm{H}$. The phenotype mar (mainly genotype $p^{M} / p^{t}$; see Halkka, Halkka, Raatikainen and Hovinen, 1973) is much commoner in CZ-H (4.4 per cent) than in B ( 1.2 per cent). Farther southwest, in Italy, the frequency of mar is as high as 10.1 per cent (Raatikainen, 1971). These differences indicate that the frequency of the $p^{M}$ allele increases southwards, 

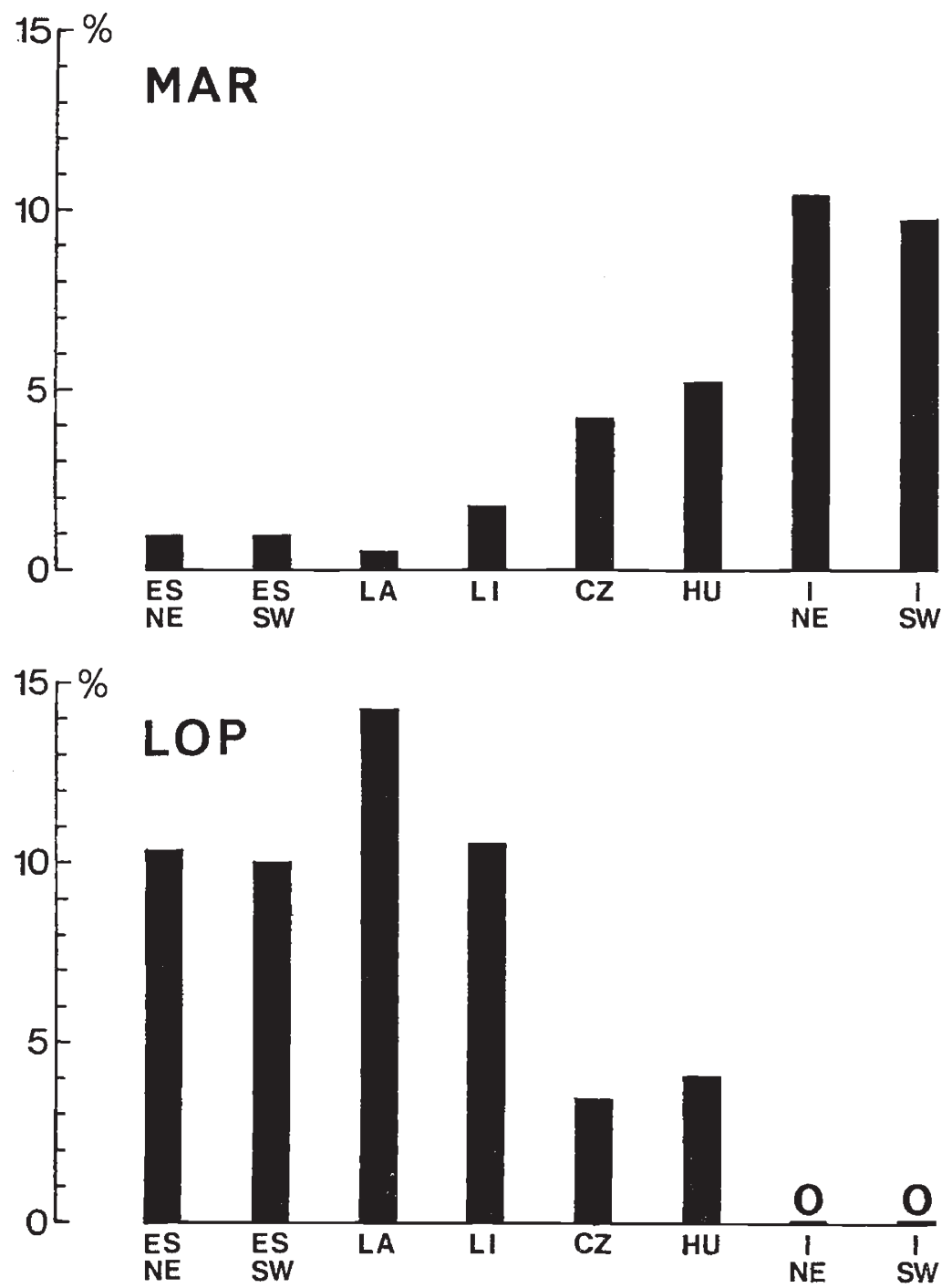

FIG. 1.- Phenotype frequency histograms for females from eight geographical groups of samples. From left to right: NE and SW Estonia, Latvia, Lithuania, Czechoslovakia, Hungary, and $\mathrm{NE}$ and $\mathrm{SW}$ parts of northern Italy.

possibly as a continuous cline (Fig. 1). The phenotype mar can, in fact, result from interaction of $p^{L}$ with either $p^{F}$ or $p^{C}$, as well as from $p^{M}$ (table 3 ). But in Central Europe the frequencies of the $p^{L} / p^{F}$ and $p^{L} / p^{C}$ heterozygotes are negligible compared with the pooled frequency of the $p^{M}$ heterozygotes. This is true because $p^{L}$ is very rare in all the three regions, B, CZ-H and Italy (see below).

A cline in the reverse direction appears probable from the frequencies of the allele $p^{0}$. The lop group of phenotypes determined by this allele has an average frequency of 10.2 per cent, in the 20 populations of $B$, but only of 3.4 per cent in the 7 populations of $\mathrm{CZ}-\mathrm{H}$. In the samples collected by 
Raatikainen (1971) from northern Italy, this group comprises only 1.4 per cent of the (female) individuals. Again, B and Italy are very dissimilar in allele frequency, and $\mathrm{CZ}-\mathrm{H}$ is intermediate.

In the dominance hierarchy, the allele $p^{O}$ is close to the bottom (table 3 ). The only allele recessive to it, $p^{t}$, is about equally common in $\mathrm{B}, \mathrm{CZ}-\mathrm{H}$ and Italy (see below). The cline in the frequency of lop (fig. 1) must therefore reflect a cline in the frequency of $p^{O}$.

No such pronounced regional differences are manifested by the other five established alleles, $p^{T}, p^{L}, p^{F}, p^{C}$ and $p^{\ell} . p^{T}$ is the top dominant allele in the dominance hierarchy series in both sexes and therefore always detectable by the presence of the appropriate phenotype, tri. This phenotype is rather low

TABLE 3

The relevant allele combinations and the corresponding phenotypes (in the female sex)

$\begin{array}{llllllll} & p^{T} & p^{M} & p^{L} & p^{F} & p^{C} & p^{O} & p^{t} \\ p^{M} & \text { tri } & \text { mar } & \text { mar } & \text { mar } & \text { mar } & \text { mar } & \text { mar } \\ p^{L} & \text { tri } & \text { mar } & \text { lat } & \text { mar } & \text { mar } & \text { lat } & \text { lat } \\ p^{O} & \text { tri } & \text { mar } & \text { lat } & \text { fla } & \text { la } & \text { lop } & \text { lop }\end{array}$

in frequency in B (3.0 per cent), as well as in CZ-H (2.7 per cent). Nor is it common in Italy (1.6 per cent; Raatikainen, 1971). As almost all the tri individuals are heterozygotes, the average frequencies of the $p^{T}$ allele in the three regions mentioned are about $0.015,0.014$ and 0.008 , respectively.

The frequency of colour morph lat (allele $p^{L}$ ) in B is $1 \cdot 1$ per cent, in CZ-H 0.6 per cent, and in Italy (Raatikainen, 1971) 2.0 per cent. The allele $p^{L}$, although rare in $\mathrm{B}$, was found in 18 of the 20 populations from this region. This allele is only exceptionally expressed in the males, and the frequencies have all been calculated for the female sex only.

The phenotype $f a$ (allele $p^{F}$, or $p^{C}$ ) is more frequent than either tri or lat in both $\mathrm{B}$ and $\mathrm{CZ}-\mathrm{H}$ (table 1). A point worth noting although not indicated in the table, is that the majority of the $f a$ individuals in CZ-H belong to the fla-2 phenotype described by Raatikainen (1971). Previously, this phenotype was known only from Italy.

The phenotypes gib and lce (allele $p^{C}$ ) are about equally frequent in B ( 2.2 per cent) and CZ-H (2.9 per cent). In northern Italy, Raatikainen (1971) found only one gib and no lce among 2116 females.

The phenotypes vit and pra are rather rare in both $\mathrm{B}$ and $\mathrm{CZ}-\mathrm{H}$, and also in northern Italy (Raatikainen, 1971). The genetic basis of these colour morphs is unknown, but they may well be determined by specific alleles, " $p^{V}$ " and " $p^{P} "$. If these alleles really exist, the number of alleles at the $p$ locus in the central European populations is (at least) 9.

The assembly of phenotypes grouped under the denomination typ, although the last to be considered, is not least in importance. In the females, the allele determining this group of phenotypes, $p^{t}$, is the bottom recessive. All the typ females are thus $p^{t} / p^{t}$, which means that $\left(p^{t}\right)^{2}$ frequencies can be read directly from table 1 . Within the typ group, phenotypic variability is much more extensive in the south than in the north of Europe. Taking the group as a whole, no great difference with regard to its frequency exists between $\mathrm{B}(72.8$ per cent) and $\mathrm{CZ}-\mathrm{H}$ (77.0 per cent). In Italy, according to Raatikainen (1971), the corresponding frequency is 77.8 per cent. As shown by these values, the average frequency of the allele $p^{\ell}$ exceeds 0.8 in all three 
regions. A typical feature of the colour polymorphism of Philaenus is that much of the geographical variability in allele frequencies occurs as a "fine adjustment" of the relative frequencies of the rare alleles. Although these 6 (or perhaps 8, see above) alleles together comprise only about 0.2 of the total, their frequencies may be very sensitive indicators of variation in the external environment.

\section{Discussion}

The mean temperature of July is about $17^{\circ} \mathrm{C}$ in the Baltic States, $21^{\circ} \mathrm{C}$ in Hungary, and the same in northern Italy. Between B and CZ-H, there is no great difference in the mean temperature of January, but Italy (about $0^{\circ} \mathrm{G}$ ) differs from Hungary $\left(-2^{\circ} \mathrm{C}\right)$. These differences in climate between the three regions may well affect the various colour morphs dissimilarly. In northern Europe, the colour phenotypes have been shown to differ in their "north tolerance", i.e. their limits of distribution do not coincide and in some cases differ widely (Halkka, Raatikainen and Halkka, 1974).

The populations of Northern Europe (Sweden and Finland) are separated from those of the Baltic States by the Baltic Sea. This sea appears to constitute an effective barrier to the migration of many animals, including Philaenus. The populations of southern Finland and northern Estonia, although only about $50 \mathrm{~km}$ apart, show profound differences in allele frequencies (Halkka et al., 1973). Thus, either a cline or an abrupt transition in gene frequencies exists in the chain of populations (about $400 \mathrm{~km}$ long) occupying the terrain bordering the Gulf of Finland between Toila (table 1) and southeastern Finland. In this chain the morphs pra and vit, which are present in Estonia but absent from continental Finland, reach their northern limits. The dropping out of these, and the changes in the frequencies of the other morphs, may be due to transitions in climate or in some other factors that vary concomitantly with climate.

In polyphagous herbivores like Philaenus or Cepaea, climate may influence allele frequencies either directly or via regional peculiarities in the distribution of the most important food-plant species. In Philaenus, the colour morphs differ in their choice of food-plants (Halkka, in preparation). In studies on the selective mechanisms, an experimental approach or direct field observation (for Cepaea, Richardson, 1974) is usually necessary before a decision can be made on whether climatic variables act directly or indirectly.

Some of the apparent differences of opinion about the effects of climatic selection, frequent in the literature on Cepaea (e.g. Guerrucci-Henrion 1966; Harvey, $1971 a, b)$ may be due to the complexity of the indirect actions of such selection. Nothing has been reported about whether the colour morphs of Cepaea differ in their choice of food-plants.

Some of the principles governing climatic selection in Cepaea were proposed in the fifties (Lamotte, 1959), and more recent work is concerned with clarifying the relative significance of visual and non-visual selection. Arnold (1971) and others have presented evidence that in areas with reduced visual selection the impact of climatic selection is pronounced. Regional differences in the intensity of predation, as observed in Cepaea, have not been reported for Philaenus. In the spittlebug, visual selection has been claimed to operate by the apostatic principle (Owen and Wiegert, 1962), or by the principle of warning coloration (Thompson, 1973). Neither hypothesis has 
been corroborated by experiments or observations in the field. A comprehensive search of the literature on food lists of well over 100 species of European birds is now in progress, but as yet has failed to disclose any effective predator of Philaenus (Halkka and Kohila, in preparation). So far, there are no grounds for expecting visual selection to discriminate in any way between the apparently non-cryptic black-and-white phenotypes (mar, lat and lce, for instance).

In conclusion, we suggest that gradients of climatic severity (or some concomitant) along the transect from Italy (about $44 \mathrm{~N}$ ) to Estonia (about $59 \mathrm{~N}$ ) account for the clines and other regional differences in the frequencies of $p$ alleles in Philaenus. The suggested clines cross the centre of the range of this species in Europe.

There is very little overlap between the geographical regions where studies have been made on morph or gene frequencies in natural populations of Cepaea and Philaenus. It would perhaps be rewarding to make studies on Philaenus in the localities used in investigations on the ecological genetics of snails. Ecologically snails and spittlebugs are probably largely independent of each other, and it would be of interest to examine whether there is any parallelism in clines or area effects.

Acknowledgments.-We are grateful to Dr Milos Musil (Brno, Czechoslovakia), Dr K. Vilbaste (Tartu, Estonia), and Dr A. Murtomaa (Tikkurila, Finland) for effective help in the field work phase of the investigations. Mrs Tarja Kohila, B.Sc., skilfully helped in processing the work for printing. Grants for the study have been received from the National Research Council of Sciences of the Academy of Finland.

\section{REFERENGES}

ARNold, R. w. 1971. Cepaea nemoralis on the East Sussex South Downs, and the nature of area effects. Heredity, 26, 277-298.

GUERRUCGI-HENRION, M. A. 1966. Recherches sur les populations naturelles de Cepaea nemoralis en Bretagne. Arch. Zool. Exp. Gen., 107, 369-417.

HALKKA, O. 1964. Geographical, spatial and temporal variability in the balanced polymorphism of Philaenus spumarius. Heredity, 19, 383-401.

HALKKA, O., HALKKA, L., RAATIKAINEN, M., AND HOVINEN, R. 1973. The genetic basis of balanced polymorphism in Philaenus (Homoptera). Hereditas, 74, 69-80.

halKKa, O., RAATIKAINEN, M., AND HALKKA, L. 1974. Radial and peripheral clines in northern polymorphic populations of Philaenus spumarius. Hereditas, 78, 85-96.

HALKKA, O., HALKKa, L., hovinen, R., RAATikAinen, M., AND VASARAINEN, A. 1975. Genetics of Philaenus colour polymorphism: the 28 genotypes. Hereditas, 79, 308-310.

ifarvey, p. 1971 a. Cepaea nemoralis in Brittany, Cornwall and Pembrokeshire. Heredity, 26, 365-372.

HARVEY, P. 1971b. Populations of Cepaea nemoralis from southwestern France and northern Spain. Heredity, 27, 353-363.

JONES, J. s. 1973. Ecological genetics and natural selection in molluscs. Science, 182, 546552.

цамотте, м. 1959. Polymorphism of natural populations of Cepaea nemoralis. Cold Spring Harbor Symp. Quant. Biol., 24, 65-84.

OWEN, D. F., AND WIEGERT, R. G. 1962. Balanced polymorphism in the meadow spittlebug, Philaenus spumarius. Amer. Naturalist, 96, 353-359.

RAATIKarnen, M. 1971. The polymorphism of Philaenus spumarius (L.) (Homoptera) in Northern Italy. Ann. Ent. Fenn., 37, 72-79.

RIGHARDSON, A. M. M. 1974. Differential climatic selection in natural populations of land snail Cepaea nemoralis. Nature, 247, 572-573.

THOMPson, v. 1973. Spittlebug polymorphic for warning coloration. Nature, 242, 126-128. 